\title{
Changes in Vegetation Proprieties under Short- and Long-Term Protection in North African Arid Land
}

\author{
Fathia Abdallah*, Mohamed Chaieb \\ Department of Biology, Faculty of Sciences, University of Sfax, Sfax, Tunisia \\ Email: ${ }^{*}$ f.abdallah1@voila.fr
}

Received 9 December 2013; revised 5 February 2014; accepted 26 February 2014

Copyright (C) 2014 by authors and Scientific Research Publishing Inc.

This work is licensed under the Creative Commons Attribution International License (CC BY). http://creativecommons.org/licenses/by/4.0/

(c) (i) Open Access

\begin{abstract}
The objective of this study was to quantify the effects of protection on herbaceous species composition, total plant cover, dry matter, plant density, floristic richness and diversity. Characteristics of vegetation under continued grazing and protected area for 10 and 65 years were examined in a degraded arid environment in South Tunisia. Our results show that protection enhances significantly (two times) different vegetation parameters. However, long-term protection was found to reduce biomass production, plant density and floristic diversity. Some palatable species such as Stipagrostis ciliata, Helianthemum sessiliflorum, Eragrostis papposa, Echiochilon fruticosum and Cenchrus ciliaris were frequently found in the protected sites. In the grazed site, these species were being replaced by less desirable species: Astragalus armarus, Peganum harmala and Artemisia compestris. This emphasized the importance of conservation stocking rates and proper pasture management.
\end{abstract}

\section{Keywords}

Arid environment; Protection; Vegetation; Grazing

\section{Introduction}

Livestock grazing is one of the main causes of degradation in arid and semi-arid ecosystems [1]-[3]. Grazing frequently operates through the reduction of plant cover and fragmentation followed by disappearance of vegetation patches, reducing their size and/or numbers [4] and leading to soil erosion and losses of nutrients from the exposed soil [5]. Grazing increased, reduced or lacked consistent effect on plant diversity [6]. These contrasting

Corresponding author.

How to cite this paper: Abdallah, F. and Chaieb, M. (2014) Changes in Vegetation Proprieties under Short- and Long-Term Protection in North African Arid Land. American Journal of Plant Sciences, 5, 899-906. 
patterns of response were attributed to differences in grazing intensity, with greatest diversity expected at intermediate levels of grazing [7] [8]. Indeed, the protection or exclosure is considered as an effective approach for the restoration of soil and vegetation. However, lack of replication, unreliable measurement techniques, and inadequate duration of exclusion treatments has made it difficult to draw definitive conclusions from these studies [9].

In spite of the importance assigned to the protection, the main aim of this study was to investigate vegetation dynamics in Tunisian arid environment. Vegetation characteristics were compared in the grazed area and protected area after 10 and 67 years of exclosure.

\section{Materials and Methods}

\subsection{Study Area}

The experiment was carried out in three sites located in Bou Hedma National region (South of Tunisia, Figure 1) and differing in grazing intensity. The two first sites, inside Bou Hedma National park were submitted to light grazing (the stocking density is about 1 animal per $40 \mathrm{ha}$ ), however the third in the neighboring pastoral grazing land is heavily grazed by sheep and goats (the stocking density equal to about 2 animals per ha). Bou Hedma National Park ( $34^{\circ} 39^{\prime} \mathrm{N}$ and $\left.9^{\circ} 48^{\prime} \mathrm{E}\right)$, is characterized by an arid Mediterranean bioclimate with a moderate winter [10]. The mean annual rainfalls vary between 100 and $200 \mathrm{~mm}$. The annual mean temperature is about $17.2^{\circ} \mathrm{C}$ while the minimal and maximal monthly temperature means were respectively $3.8^{\circ} \mathrm{C}$ (December and January) and $36.2^{\circ} \mathrm{C}$ (July and August).

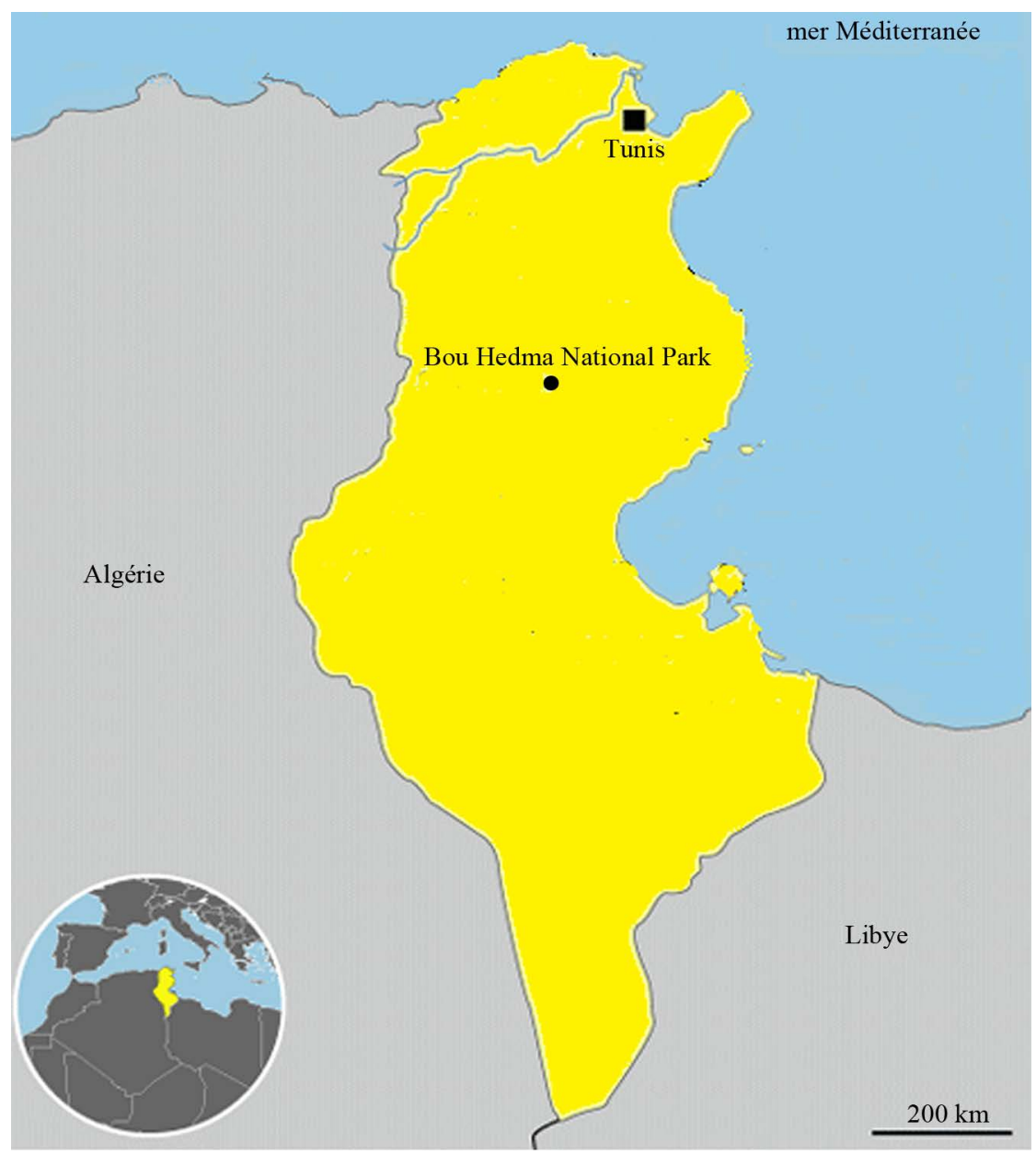

Figure 1. Localization of the study sites inside and outside the Bou Hedma National Park (South Tunisia). 
The soils are sandy to sandy loam soils, medium and coarse textured, undeveloped due to old and clastic deposit of Quaternary age on the slopes of Jebel torn by water erosion and covered by Acacia tortilis subsp. raddiana pseudo-savanna in association with perennial herbaceous species such as Cenchrus ciliaris, Hammada schmittiana, Hammada scoparia.

\subsection{Climatic Conditions during the Investigation Periods}

The studied year (2001/2002 growing seasons) was a wet season since the annual precipitation reached 146.4 $\mathrm{mm}$ (Figure 2). Precipitation started with a good quantity during the month of October $(48.6 \mathrm{~mm})$ and was well distributed in time, witch facilities the annual species appearance and the starting of the perennial species development.

\subsection{Vegetation Sampling}

The present study was conducted during the spring of 2002, period of peak vegetation cover. Three sites were selected for sampling. The first area (Gr) is continually grazed. The second area (10 pr) had been protected for 10 years at the time of this research. The third area $(65 \mathrm{pr})$ had been protected for 65 years.

In the first study site, 43 (20 m long) transects were, random, set up in order to measure the floristic composition, total plant cover and individual species cover using the quadrat point method [11]. In the same way, 43 transects were placed at the level of the second and third study site. Observations were made every $10 \mathrm{~cm}$, for a total of 200 points along each transect to determine total plant cover (\%) and cover (\%) of each herbaceous species sampled.

Density of perennial species per square meter was determined within forty three $20 \mathrm{~m}^{2}$ area quadrats in the two protected site and 43 in the grazed site.

Dry matter was assessed by the formula of Le Houérou (1987) [12]: DM $\left(\mathrm{kg}^{\circ} \mathrm{ha}{ }^{-1}\right)=r \times 43.1 \pm 3.6$ where $r$ is the perennial species cover.

The importance and the distribution of species in the lightly and heavily areas were studied using the Shannon-Weaver index [13]. This index is defined by the following formula: $H^{\prime}=-\Sigma P_{i} \log _{2} P_{i}$ with $P_{i}=n_{i} / n$ where $P_{i}$ is the relative frequency of the species; $n_{i}$, the mean cover of the species $i$, and $n$ the total cover of all species.

\subsection{Data Analysis}

We evaluated the effect of protection on vegetation parameters by using one-way ANOVA, with grazing management as fixed factor. ANOVA analyses were conducted with the SPSS (11.5). The values of the probability lower than $0.05(\mathrm{p}<0.05)$ were regarded as statistically significant.

\section{Results}

Protection generates a significant increase of total plant cover. The total plant cover was 1.6 and 2.4 times greater

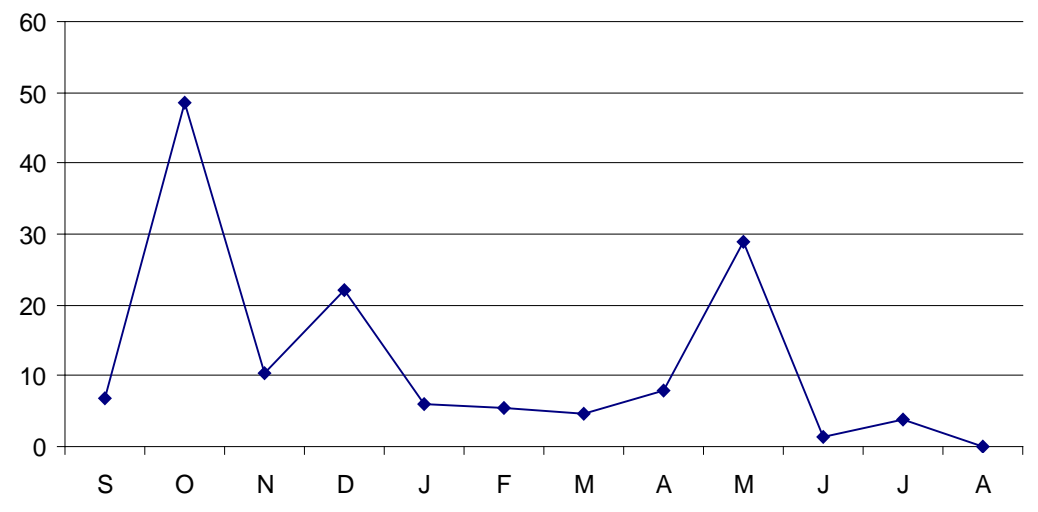

Figure 2. Monthly rainfall (in $\mathrm{mm}$ ) recorded at Bou Hedma National Park during the growing year (2001/2002). 
in the 10 ex and 65 than the grazed area (Figure 3(a)). Mean values ranged between 31\% in Gr and 50\% to $72.24 \%$ in the $10 \mathrm{pr}$ and $65 \mathrm{pr}$ respectively.

In the same way the present study showed that plant density was significantly affected by grazing intensity ( $p$ $<0.05$ ). The plant density in the $65 \mathrm{pr}$ and $10 \mathrm{pr}$ was respectively 2 to 2.47 times higher than the plant density in the Gr (Figure 3(b)). These results agree with those cited by Gardner (1950) which shows, also, a significant increase of plant density under protected area compared to grazed areas.

Calculated dry matter also increased significantly under protection condition. With the increase of exclusion time (Figure 3(c)). Mean values were 1.67 and 3.19 times higher in $65 \mathrm{pr}$ and $10 \mathrm{pr}$ respectively, than in Gr. Significant differences were found between the three grazing regimes.
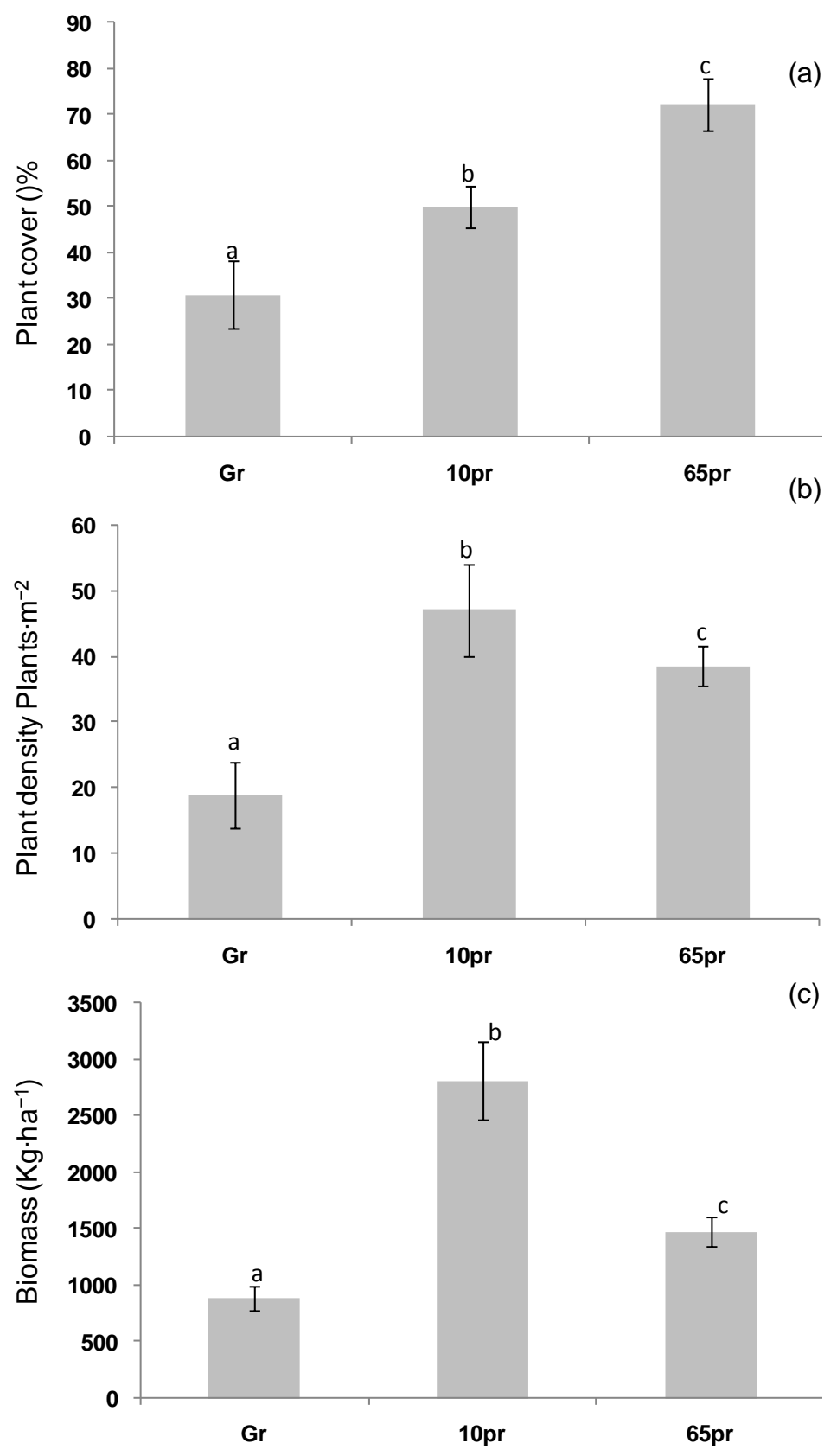

Figure 3. Variations of total plant cover (\%), perennial density (Plants $\cdot \mathrm{m}^{-2}$ ) and biomass $\left(\mathrm{kg} \cdot \mathrm{ha}^{-1}\right)$ with protection age (Values having the same letter are not significantly different). 
In other hand, our study shows that protection influenced positively the species richness and the ShannonWiener diversity index. Indeed, species richness did not exceed 19 in the Gr, but it reached respectively 23 and 29 in the $10 \mathrm{pr}$ and $65 \mathrm{pr}$ (Figure 4(a)).

However, we should note that the Shannon-Weaver index $H^{\prime}$, relatively higher in the grazed area (Figure 4(b)).

In terms the of floristic composition (Table 1), statistical analysis of the species cover produced significant differences for some palatable species such as Stipagrostis ciliata, Helianthemum sessiliflorum, Eragrostis papposa, Echiochilon fruticosum, Cenchrus ciliaris and Cynodon dactylon. In the same way, the cover of some annual specie such as Chenopodium album, Paronychia arabica, Plantago ovata and Stipa capensis was significantly higher inside the two protected area compared to the grazed site.

Some less palatable species (Astragalus armarus, Peganum harmala and Artemisia compestris) are significantly frequent outside the park $(p<0.05)$. A non-significant difference was found between sites for other species such as Polygonum equisetiforme, Onopordum espinae, Medicago truncatula, Lotus creticus, Euphorbia retusa, Astragalus corrugatus, Asphodelus tenuifolius and Argyrolobium uniflorum. Their cover varied between $0 \%$ and $0.33 \%$ in the grazed area and between $0 \%$ and $0.55 \%$ in the protected area.

\section{Discussions}

In accordance with Brown and Al Mazrooei (2003) [14] and Belsky (1992) [15], this study shows that the total plant cover was higher in the two protected areas than in the grazed area. Other studies have also shown that cessation of grazing can increase plant cover [16] [17]. Our results suggested that the benefic effect of this type of management increases with protection age.

A high number of individuals support the fixing of soil particles, which has a positive effect on fertility (soil
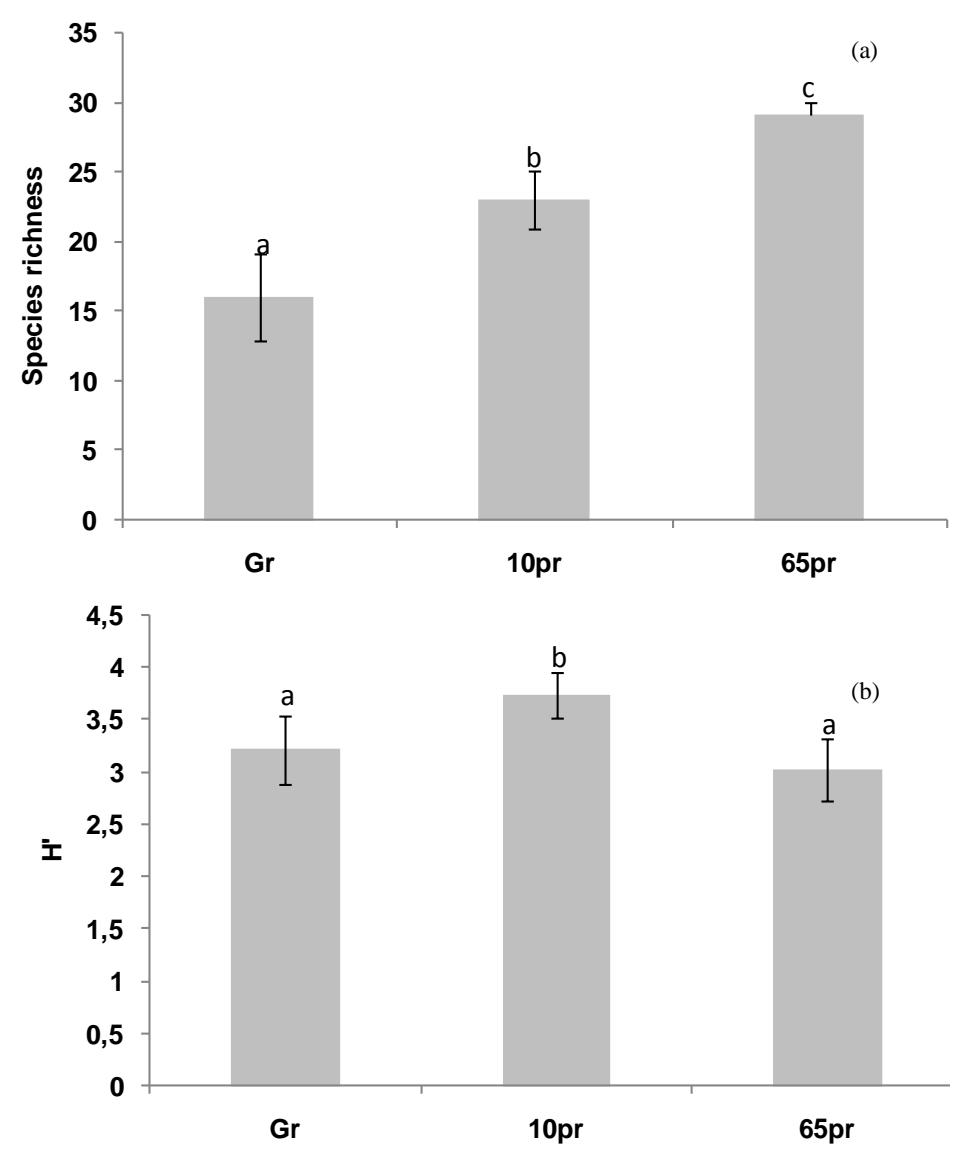

Figure 4. Variation of diversity parameters (Species richness, $H^{\prime}$ ) with protection age (Values having the same letter are not significantly different). 
Table 1. Variations of herbaceous species cover (\%) occurring in the site protected since 10 year (10 pr), 65 year (65 pr) and in the grazed site (Gr).

\begin{tabular}{|c|c|c|c|c|}
\hline & Gr & $10 \mathrm{pr}$ & $65 \mathrm{pr}$ & $p$ \\
\hline Argyrolobium uniflorum & $0.28 \pm 0.02$ & $0.04 \pm 0.01$ & $0.55 \pm 0.21$ & NS \\
\hline Artemisia compestris & $1.58 \pm 0.63$ & $0.69 \pm 0.04$ & 0 & $*$ \\
\hline Asphodelus tenuifolius & 0 & 0 & $0.11 \pm 0.10$ & NS \\
\hline Astragalus armatus & $4.32 \pm 0.44$ & $0.56 \pm 0.07$ & 0 & $*$ \\
\hline Astragalus corrugatus & 0 & 0 & $0.22 \pm 0.01$ & NS \\
\hline Atriplex halimus & $1.53 \pm 0.15$ & $0.03 \pm 0.01$ & $0.32 \pm 0.07$ & NS \\
\hline Cenchrus ciliaris & $0.01 \pm 0.17$ & $7.52 \pm 0.54$ & $6.40 \pm 0.96$ & $* * *$ \\
\hline Centauria dimorpha & 0 & 0 & $0.87 \pm 0.33$ & NS \\
\hline Chenopodium album & 0 & 0 & $1.13 \pm 0.46$ & * \\
\hline Cynodon dactylon & $0.19 \pm 1.18$ & $12.98 \pm 1.66$ & $4.27 \pm 1.28$ & $* *$ \\
\hline Deverra tortuosa & $0.53 \pm 0.01$ & $4.40 \pm 0.84$ & 0 & * \\
\hline Diplotaxis simplex & 0 & 0 & $1.44 \pm 0.26$ & NS \\
\hline Diplotaxis harra & 0 & 0 & $1.73 \pm 0.11$ & NS \\
\hline Echiochilon fruticosum & $0.43 \pm 0.220$ & $3.53 \pm 0.01$ & 0 & NS \\
\hline Enarthrocarpus clavatus & 0 & 0 & $3.36 \pm 1.25$ & $*$ \\
\hline Eragrostis papposa & 0 & 0 & $7.54 \pm 1.67$ & * \\
\hline Euphorbia retusa & 0 & 0 & $0.02 \pm 0.05$ & NS \\
\hline Fagonia cretica & $1.05 \pm 0.12$ & $0.23 \pm 0.03$ & $1.04 \pm 0.19$ & NS \\
\hline Gymnocarpos decander & 0.85 & $1 \pm 0.01$ & 0 & $*$ \\
\hline Hammada schmittiana & $0.02 \pm 0.01$ & $9.38 \pm 0.22$ & $3.88 \pm 1.08$ & $*$ \\
\hline Hammada scoparia & 0 & $4.31 \pm 0.10$ & $1.52 \pm 0.41$ & * \\
\hline Helianthemum kahiricum & 0 & $1.91 \pm 0.30$ & 0 & NS \\
\hline Helianthemum sessiliflorum & 0 & $2.03 \pm 0.32$ & 0 & NS \\
\hline Launaea resedifolia & 0 & 0 & $0.01 \pm 0.01$ & NS \\
\hline Lotus creticus & 0 & 0 & $0.38 \pm 0.24$ & NS \\
\hline Lycium chawii & $1.74 \pm 0.05$ & $1.36 \pm 0.04$ & $0.55 \pm 0.14$ & NS \\
\hline Malva aegyptiaca & 0 & 0 & $2.02 \pm 0.74$ & NS \\
\hline Marrubium deserti & 0 & $3.46 \pm 0.02$ & 0 & $*$ \\
\hline Medicago truncatula & 0 & 0 & $0.32 \pm 0.04$ & NS \\
\hline Neurada procumbens & 0 & 0 & $1.03 \pm 0.26$ & NS \\
\hline Onopordum espinae & 0 & 0 & $0.15 \pm 0.03$ & NS \\
\hline Paronychia arabica & 0 & 0 & $43.19 \pm 7.12$ & $* * *$ \\
\hline Peganum harmala & $1.52 \pm 0.02$ & $0.08 \pm 0.01$ & 0 & * \\
\hline Plantago albicans & $1.67 \pm 0.41$ & $0.39 \pm 1.12$ & $0.40 \pm 0.15$ & NS \\
\hline Plantago ovata & 0 & 0 & $20 \pm 4.14$ & $* * *$ \\
\hline Polygonum equisetiforme & $0.33 \pm 0.01$ & $0.44 \pm 0.01$ & 0 & NS \\
\hline Reseda alba & 0 & 0 & $0.33 \pm 0.21$ & NS \\
\hline Rhanterium suaveolens & $0.40 \pm 0.03$ & $5.94 \pm 0.41$ & $0.41 \pm 0.26$ & $*$ \\
\hline Salsola vermiculata & 0 & $1.42 \pm 0.11$ & 0 & NS \\
\hline Salsola villosa & 0 & 0 & $0.10 \pm 0.08$ & NS \\
\hline Salvia aegyptiaca & 0 & $2.13 \pm 0.69$ & 0 & NS \\
\hline Schismus barbatus & 0 & 0 & $0.63 \pm 0.22$ & NS \\
\hline Stipa capensis & 0 & 0 & $10.07 \pm 2.58$ & $* *$ \\
\hline Stipagrostis ciliata & 0 & $1.65 \pm 0.06$ & 0 & * \\
\hline Stipagrostis plumosa & 0.21 & $0.19 \pm 0.03$ & $0.06 \pm 0.03$ & NS \\
\hline
\end{tabular}


organic matter decomposition and nutrient dynamics) and water balance of soil (reduction of evapo-transpitation). However, a decrease of plant density was recorded in the 65 pr compared with 10 pr.

Conversely, the decrease of total plant cover and perennial species density in the highly grazed area can be possibly due to a long history of over-grazing. These results are in agreement with those obtained by YongZhong et al. (1989) [18] in China and by Jeddi and Chaieb (2010) [19] in South Tunisia. Noy-Meir et al. (2005) [20] reported that when there is a decrease in perennials grasses whose superficial roots encourage soil aeration, there is a decrease of water infiltration coupled with ligneous species reduction.

The increase of dry matter production agrees with those of Shaltout et al., (1996) [21] which indicated that the maximum biomass was attained after 2 years of protection, after dropping dramatically inside but not outside the protected area. This author concluded that both continuous protection and continuous free grazing have deleterious effects on vegetation.

Other studies in similar habitats have shown that four years of protection had led to the regeneration of vegetation, e.g., Brown and Al Mazrooei (2003) [14], in northern Kuwait and under arid bioclimate. Manier and Hobbs (2006) [9] concluded that five decades caused minor changes in cover and diversity of herbaceous plants, but caused a clear increase in the cover of shrubs.

On the other hand, several authors [22] agree on the fact that plant diversity is strongly influenced by the degree of disturbance. This is in agreement with our results that the diversity of habitats increases with disturbance and decreases under the effect of long-term protection. Indeed, the Schannon diversity index $\left(H^{\prime}\right)$ increases regularly until 10 years (Abdallah et al. 2011) [23] to 15 years of protection. However, beyond 10 to 18 years of protection, $H^{\prime}$ decreases abruptly [24]. These results can be explained by the fact that arid Mediterranean steppes are typically dominated by therophytes under heavy anthropogenic degradation especially during rainy period, which guarantees a high diversity as we have shown.

The present results offers evidences supporting the theoretical prediction [25] that herbivore-induced changes in community composition are controlled by a suite of factors influencing ungulate selectivity and plant tolerance and herbivory. This pasture is generally selective and the palatable species are very threatened. Intense grazing of rangelands often results in highly competitive palatable species replaced by less palatable species which are often considered less desirable or even worthless plants [26]. Comparable results were reported by Primack (1993) [27]. West and Smith (1997) [28] and Aronson and Le Floc'h (1995) [29] also recorded a rare faction of good pastoral value species in the grazed areas.

\section{References}

[1] Li, C.L., Hao, X.Y., Zhao, M.L., Han, G.D. and Willms, W.D. (2008) Influence of Historic Sheep Grazing on Vegetation and Soil Properties of a Desert Steppe in Inner Mongolia. Agriculture, Ecosystems \& Environment, 128, 109-116. http://dx.doi.org/10.1016/j.agee.2008.05.008

[2] Yates, C.J., Norton, D.A. and Hobbs, R.J. (2000) Grazing Effects on Plant Cover, Soil and Microclimate in Fragmented Woodlands in South-Western Australia: Implications for Restoration. Austral Ecology, 25, 36-47. http://dx.doi.org/10.1046/j.1442-9993.2000.01030.x

[3] Huang, D., Wang, K. and Wu, W.L. (2007) Dynamics of Soil Physical and Chemical Properties and Vegetation Succession Characteristics during Grassland Desertification under Sheep Grazing in an Agro-Pastoral Transition Zone in Northern China. Journal Arid Environment, 70, 120-136. http://dx.doi.org/10.1016/j.jaridenv.2006.12.009

[4] Perveen, A. and Hussain, M.I. (2007) Plant Biodiversity and Phytosociological Attributes of Gorakh Hill (Khirthar Range). Pakistan Journal Botany, 39, 691-698.

[5] Holm, AM., Loneragan, W.A. and Adams, M.A. (2002) Do Variations in a Model of Landscape Function Assist in Interpreting the Growth Response of Vegetation to Rainfall in Arid Environments? Journal of Arid Environment, 50, 2352. http://dx.doi.org/10.1006/jare.2001.0857

[6] Proulx, M. and Mazumder, A. (1998) Reversal of Grazing Impact on Plant Species Richness in Nutrient-Poor vs. Nutrient-Rich Ecosystems. Ecology, 79, 2581-2592. http://dx.doi.org/10.1890/0012-9658(1998)079[2581:ROGIOP]2.0.CO;2

[7] Grime, J.P. (1973) Competitive Exclusion in Herbaceous Vegetation. Nature, 242, 344-347. http://dx.doi.org/10.1038/242344a0

[8] Connell, J.H. (1978) Diversity in Tropical Rain Forests and Coral Reefs. Science, 199, 1302-1310. http://dx.doi.org/10.1126/science.199.4335.1302

[9] Manier, D.J. and Thompson, H.N. (2006) Large Herbivores Influence the Composition and Diversity of Shrub-Steppe 
Communities in the Rocky Mountains, USA. Oecologia, 146, 641-651. http://dx.doi.org/10.1007/s00442-005-0065-9

[10] Le Houérou, H. (1959) Ecological and Floristic Researches on the Vegetation of the Southern Tunisia. Institute of Research on the Sahara, Algeria.

[11] Daget, P. and Poissonet, J. (1971) An Ecological Analysis Method of Prairies: Criteria’s of Application. Annales Agronomiques, 22, 5-41.

[12] Le Houérou, H.N. (1987) Aspects Météorologiques de la Croissance et du Développement Végétal Dans les Déserts et Les Zones Menacées de Désertification. PNUE, Nairobi et OMM, Geneve.

[13] Shannon, C.E. and Weaver, W. (1949) The Mathematical Theory of Communication. University of Illunois Press, Urbana.

[14] Brown, G. and Al Mazrooei, S. (2003) Rapid Vegetation Regeneration in a Seriously Degraded Rhanterium epapposum Community in Northern Kuwait after 4 Years of Protection. Journal of Environmental Management, 68, 387-395. http://dx.doi.org/10.1016/S0301-4797(03)00107-5

[15] Belsky, J. (1992) Effects of Grazing, Competition, Disturbance and Fire on Species Composition and Diversity in Grassland Communities. Journal of Vegetation Science, 3, 187-200. http://dx.doi.org/10.2307/3235679

[16] Anderson, L.J., Brumbaugh, M.S. and Jackson, R.B. (2001) Water and Tree-Understory Interactions: A Natural Experiment with Oak wilt in a Savanna Ecosystem. Ecology, 82, 33-49.

[17] Courtois, D.R., Perryman, B.L. and Hussein, H.S. (2004) Vegetation Change after 65 Years of Grazing and Grazing Exclusion. Journal of Range Management, 57, 574-582. http://dx.doi.org/10.2307/4004011

[18] Su, Y.-Z., Li, Y.-L., Cui, J.-Y. and Zhao, W.-Z. (2005) Influences of Continuous Grazing and Livestock Exclusion on Soil Properties in a Degraded Sandy Grassland, Inner Mongolia, Northern China. Catena, 59, 267-278. http://dx.doi.org/10.1016/j.catena.2004.09.001

[19] Jeddi, K. and Chaieb, M. (2010) Changes in Soil Properties and Vegetation Following Livestock Grazing Exclusion in Degraded Arid Environments of South Tunisia. Flora, 205, 184-189. http://dx.doi.org/10.1016/j.flora.2009.03.002

[20] Noy-Meir, I., Gutman, M. and Kplan, Y. (1989) Responses of Mediterranean Grassland Plants to Grazing and Protection. Journal of Ecology, 77, 290-310. http://dx.doi.org/10.2307/2260930

[21] Shaltout, K.H., El-Halawany, E.F. and El-Kady, H.F. (1996) Consequences of Protection from Grazing on Diversity and Abundance of Coastal Lowland Vegetation in Eastern Saudi Arabia. Biodiversity Conservation, 5, 27-36. http://dx.doi.org/10.1007/BF00056290

[22] Jauffret, S. and Lavorel, S. (2003) Plant Functional Types: Relevant to Describe Degradation in Steppes of Arid Southern Tunisia? Journal of Vegetation Science, 14, 399-408. http://dx.doi.org/10.1111/j.1654-1103.2003.tb02165.x

[23] Abdallah, F., Belgacem, A.O. and Chaieb, M. (2011) Effects of Ten Years Enclosure on Vegetation Characteristics of a National Park in South Tunisia. Acta Botanica Gallica, 158, 161-168. http://dx.doi.org/10.1080/12538078.2011.10516263

[24] Zhang, J., Zhao, H., Zhang, T., Zhao, X. and Drake, S. (2005) Community Succession along a Chronosequence of Vegetation Restoration on Sand Dunes in Horqin Sandy Land. Journal of Arid Environments, 62, 555-566. http://dx.doi.org/10.1016/j.jaridenv.2005.01.016

[25] Augustine, D.J. and McNaughton, S.J. (1998) Ungulate Effects on the Functional Species Composition of Plant Communities: Herbivore Selectivity and Plant Tolerance. Journal of Wildlife Management, 62, 1165-1183. http://dx.doi.org/10.2307/3801981

[26] Callaway, R. and Tyler, C. (1999) Facilitation in Rangelands: Direct and Indirect Effects. VI International Rangeland Congress, Townsville, 19-23 July 1999, 197-202.

[27] Primack, R.B. (1993) Essentials of Conservation Biology. Sinauer Associates, Sunderland, 564.

[28] West, N.E. and Smith, E.L. (1997) Improving the Monitoring of Rangelands. Ranglands, 19, 9-14.

[29] Le Floc’h, E. and Aronson, J. (1995) Écologie de la Restauration. Définition de Quelques Concepts de Base. Nature-Science-Sociétés, 3, 29-35. 